\title{
System Approach for Building of Calcium-Binding Sites in Proteins
}

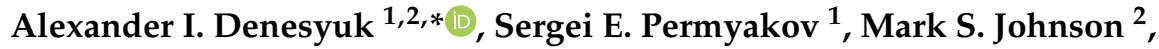 \\ Konstantin Denessiouk ${ }^{2,3}$ and Eugene A. Permyakov ${ }^{1}$ \\ 1 Institute for Biological Instrumentation of the Russian Academy of Sciences, Federal Research Center \\ "Pushchino Scientific Center for Biological Research of the Russian Academy of Sciences", Pushchino 142290, \\ Russia; permyakov.s@gmail.com (S.E.P.); epermyak@yandex.ru (E.A.P.) \\ 2 Structural Bioinformatics Laboratory, Faculty of Science and Engineering, Biochemistry, Åbo Akademi \\ University, Turku 20520, Finland; johnson4@abo.fi (M.S.J.); kdenessi@abo.fi (K.D.) \\ 3 Pharmaceutical Sciences Laboratory, Faculty of Science and Engineering, Pharmacy, Åbo Akademi \\ University, Turku 20520, Finland \\ * Correspondence: adenesyu@abo.fi; Tel.: +358-2-215-4006
}

Received: 28 February 2020; Accepted: 9 April 2020; Published: 11 April 2020

\begin{abstract}
We introduce five new local metal cation (first of all, $\mathrm{Ca}^{2+}$ ) recognition units in proteins: Clamp $_{n,(n-2)}$, Clamp $_{n,(n-1)}$, Clamp $_{n, n}$, Clamp $_{n,(n+1)}$ and Clamp $p_{n,(n+2)}$. In these units, the backbone oxygen atom of a residue in position " $\mathrm{n}$ " of an amino acid sequence and side-chain oxygen atom of a residue in position " $\mathrm{n}+\mathrm{i}$ " $(\mathrm{i}=-2$ to +2$)$ directly interact with a metal cation. An analysis of the known " $\mathrm{Ca}^{2+}$-bound niches" in proteins has shown that a system approach based on the simultaneous use of the Clamp units and earlier proposed One-Residue (OR)/Three-Residue (TR) units significantly improves the results of constructing metal cation-binding sites in proteins.
\end{abstract}

Keywords: system approach; protein structure; cation; calcium; sequence-structure motifs; building kit

\section{Introduction}

Many monographs, including ours [1,2], have been written about metal-binding proteins and metal cations. However, there are still too many uncertainties regarding how their interactions are organized. Biologically significant metals are divided into two groups: non-transition elements $(\mathrm{Na}, \mathrm{K}$, $\mathrm{Mg}, \mathrm{Ca}, \mathrm{Zn}$ ) and transition elements ( $\mathrm{Mn}, \mathrm{Fe}, \mathrm{Co}, \mathrm{Cu}, \mathrm{Mo}, \mathrm{W})$. Non-transition elements are characterized by the constancy of their oxidation state (valency) and formation of ions with incompletely filled s-electron shells or completely filled p-electron shells. In contrast, transition elements are characterized by variable valency (oxidation state) and the formation of ions with incompletely filled d-electron shells. Calcium ions, as well as magnesium, $\mathrm{Na}^{+}$and $\mathrm{K}^{+}$ions, are coordinated mainly by negatively charged oxygen atoms (see [1-3] for reviews). This is the case also for such heavy metals like Sr and Ba. The interaction is purely electrostatic. $\mathrm{Ca}^{2+}$ ions prefer a higher coordination number compared with $\mathrm{Mg}^{2+}$ ions. The usual coordination number for magnesium is six (octahedral coordination). Calcium demonstrates a lot more variety of coordination numbers, seven to nine being the most ordinary coordination numbers. The radius of the coordination sphere for calcium is essentially larger than that for magnesium: the distance from the central ion to oxygen atom is 2.0 to $2.1 \AA$ for magnesium and 2.3 to $2.6 \AA$ for calcium.

$\mathrm{Ca}^{2+}$ is a "hard" metal ion and prefers "hard" ligands with low polarizability, oxygen being the most preferable coordinating atom followed by nitrogen (reviewed by Dudev and Lim, 2003). $\mathrm{Mg}^{2+}$, like $\mathrm{Ca}^{2+}$, is also a "hard" ion and prefers "hard" oxygen-containing ligands as well. In contrast to $\mathrm{Ca}^{2+}$ and $\mathrm{Mg}^{2+}$ ions, $\mathrm{Zn}^{2+}$ ion and transition metal ions prefer "soft" polarizable ligands such as $\mathrm{S}$ and 
$\mathrm{N}$ though they are coordinated also by oxygen atoms. Here we will discuss only the binding sites for cations of non-transition metals.

Recently, we found that the structure of a metal cation-binding site in proteins can be modeled using a set of four recognition units: One-Residue (OR) units of types I and II, and Three-Residue (TR) units of types I and II (Figure 1A,B, respectively). The universal key component of all four units is the main-chain oxygen (Position $X$ ), which directly interacts with cation. We named this set as a "Building $\mathrm{Kit}^{\prime \prime}[4]$.

In the formation of the ORI/II and TRI/II units, the participation of the side-chain groups of amino acids of the tripeptide (for example, fragment Phe57-Glu59 of pike parvalbumin pI 4.10 in Figure 2A,B), in which the first amino acid includes the above-mentioned main-chain oxygen, is not obligatory. However, the side-chain oxygen atom OE1 of Glu59 (Position Y) directly interacts with calcium in pike parvalbumin (Figure 2B) [5]. The possible exclusion of the atoms of the side-chain groups of the tripeptide in the construction of ORI/II and TRI/II units can partially explain the fact that the building kit, on average, includes only $70 \%$ of the atoms that coordinate bound metal cation [4].
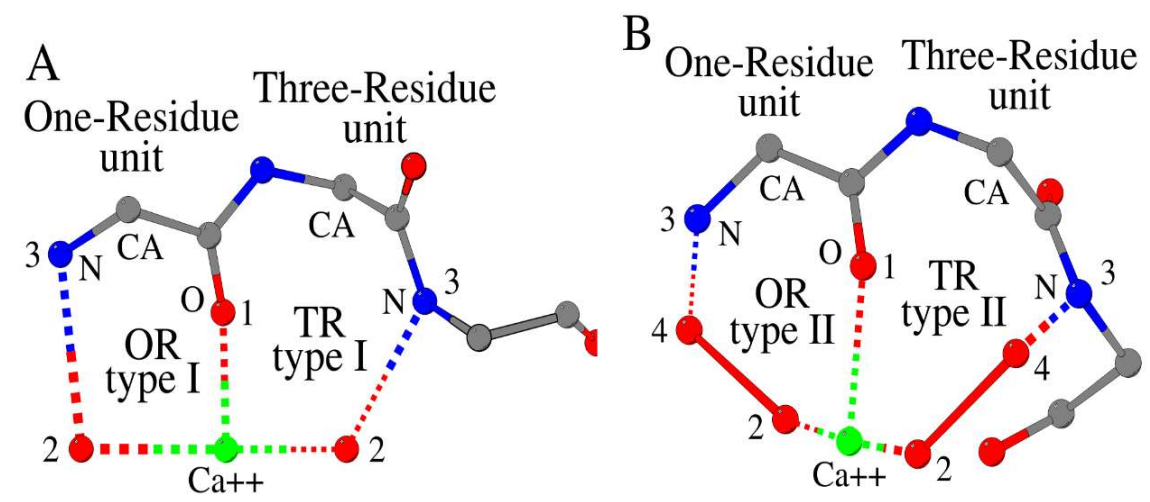

Figure 1. Metal cation-binding One-Residue (OR) and Three-Residue (TR) units, type I (A) and type II (B), in proteins. The difference between recognition by type I and type II is that the bound $\mathrm{Ca}^{2+}$ atom is linked to the main-chain nitrogen atom " 3 " through one oxygen atom ("2", type I) or two oxygens atoms (" 2 " and " 4 ", type II). The line between atoms " 2 " and " 4 " is not a covalent bond, but a rigid connection between two atoms of the same amino acid or a ligand, or two adjacent amino acids (n) and $(n-1) /(n) /(n+1)$. Amino acid atoms, water molecules and ligand atoms (carbon as gray, nitrogen as blue and oxygen as red) and cations as green are shown using the ball-and-stick model.

On the other hand, we have also shown that the side-chain atom OG (Position Y) of amino acid Ser55 in pike parvalbumin, which is located symmetrically with respect to amino acid Glu59 relative to amino acid Phe57 in the pentapeptide, participates in the formation of the ORI unit (Figure 2A) [4]. This is due to the fact that the fragment Ser55-Phe57 forms the widespread secondary structure D/N/S/T-turn [6-8].

Here, we have analyzed the role of the side-chain groups of a pentapeptide, in which the main-chain oxygen of the central amino acid directly binds the cation, in the formation of both ORI/II, TRI/II units and new local cation-binding structures. 
A

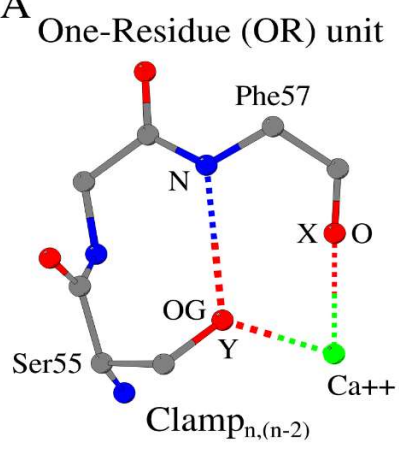

B

Three-Residue (TR) unit

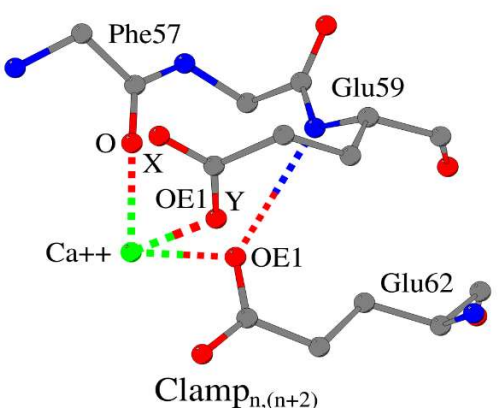

$\mathrm{D}$

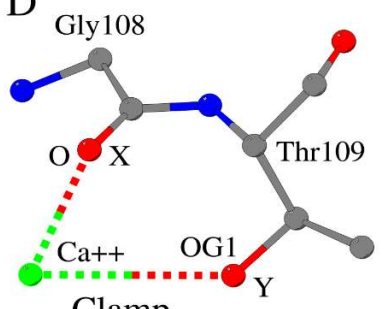

$\mathrm{Clamp}_{\mathrm{n},(\mathrm{n}+1)}$
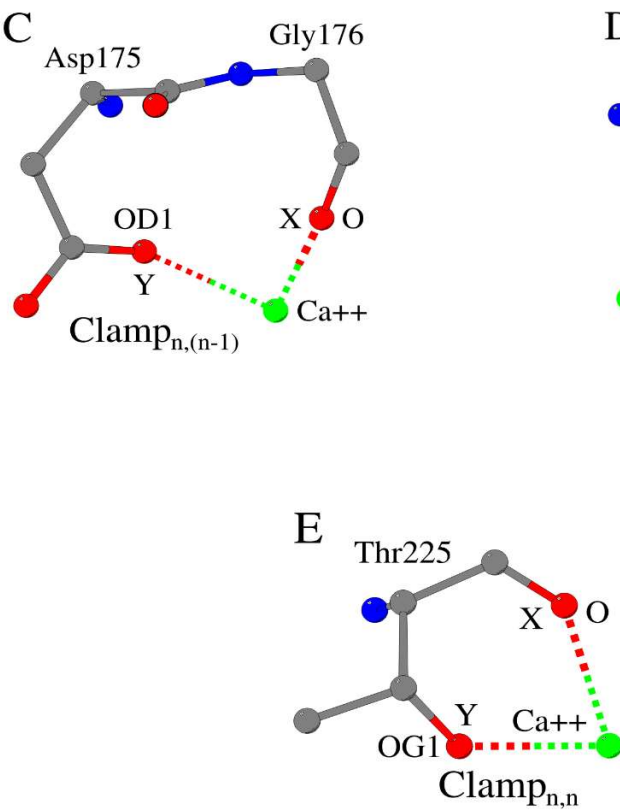

Figure 2. Five different types of local metal ion recognition substructures, observed in proteins:

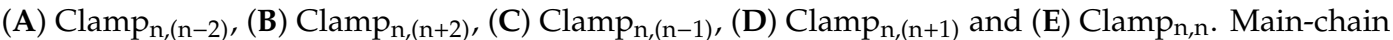
and side-chain oxygen atoms, which directly coordinate the metal cation, are shown as " $\mathrm{X}$ " and " $\mathrm{Y}$ ".

\section{Materials and Methods}

This publication is a continuation of our work on the identification of four local $\mathrm{Ca}^{2+}$-recognition units in proteins named ORI/II and TRI/II [4]. Previous analysis of metal cation-binding sites was carried out using 20 non-redundant structures with metal-bound functional "niches" [9] and 386 representative X-ray structures ( $\leq 30 \%$ sequence identity; resolution $\leq 1.50 \AA$ ) with bound $\mathrm{Ca}^{2+}$ atoms taken from the Protein Data Bank (PDB) $[10,11]$. The 20 "targeted" structures satisfied the following criterion: they contained a metal cation, which was bound to a main-chain carbonyl oxygen atom. A detailed justification for the selection of such a set of proteins was given in publication [4]. As a result, 25 PDB files were presented in the publication as three-dimensional structures containing various variants of the ORI/II and TRI/II units. Now we have analyzed the metal cation-binding sites in these 25 proteins and additionally in two $\mathrm{Ca}^{2+}$-binding proteins subtilisin Nat (PDB ID 3VYV) and annexin V (PDB ID 2IE7). We added these two proteins to the analysis since the structural organization of their $\mathrm{Ca}^{2+}$-binding sites is different from that of the $\mathrm{Ca}^{2+}$-binding sites in the homologous proteins subtilisin Carlsberg (PDB ID 1R0R) and annexin III (PDB ID 1AXN) in the 25-membered set.

Structure visualization and structural analysis of interactions between metal cations and the surrounding protein atoms was carried out using the Discovery Studio Modeling Environment 
(Dassault Systèmes BIOVIA, Discovery Studio Modeling Environment, Release 2017, San Diego: Dassault Systèmes, 2016) and the Ligand-Protein Contacts (LPC) software [12]. Color figures were produced with MOLSCRIPT [13].

\section{Results and Discussion}

\subsection{Metal Cation-Binding Clamp ${ }_{n,(n-2)}$ Unit}

We have analyzed the structures of calcium-binding sites in 27 proteins. It turned out that any calcium-binding site can be represented by a combination of separate elementary structural units. We called these units "Clamps". The Clampn,(n-2) structural unit for metal binding can be described in terms of atoms that directly interact with a metal cation (Figure 2A). For example, in pike parvalbumin pI 4.10 (PDB ID 2PVB_A, Resolution $(R)=0.91 \AA$ ) [5]) the backbone oxygen atom of Phe57n (Position X) and side-chain oxygen atom of Ser55 ${ }_{n-2}$ (Position Y) directly interact with calcium (Table 1, Columns 5 and 6). Side-chain OG hydroxyl group of Ser55 also plays the role of an "atom-mediator" or bridging atom for the main-chain nitrogen of Phe57 and calcium [5]. As a result, the $\mathrm{ORI}_{1}$ "basic" unit is formed (Figure 1A, Table 1, Column 7 [4]). We used the term "basic" to emphasize the identity of the backbone

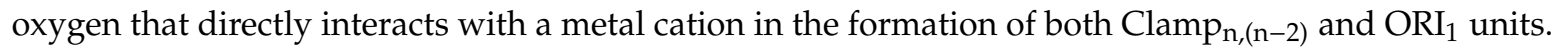
The side-chain oxygen atom of Ser55 does not take part in the formation of any other OR or TR "extra" units (Table 1, Not Applicable or Not Appropriate (N/A) in Column 8). We used the term "extra" to emphasize that in the formation of any other OR or TR units, main-chain oxygen other than the main-chain oxygen of Phe57 must be used. Thus, Table 1 contains data not only about the atoms involved in the formation of the Clamp $\mathrm{p}_{n,(\mathrm{n}-2)}$ structural unit, but also data on the atoms involved in the formation of ORI/II and TRI/II units (Table 1, Columns 7 and 8 [4]). For example, a consideration of the location of Phe57 in pike parvalbumin pI 4.10 shows that it has both Clamp $p_{n,(n-2)}$ and ORI1 structural units in its calcium-binding site.

Table 1. Existence of the Clamp $n,(n-2)$ unit in the metal cation-binding sites of proteins with "niche" motifs in these sites.

\begin{tabular}{|c|c|c|c|c|c|c|c|c|}
\hline $\mathbf{N}$ & Protein & PDB ID, R (Å) & Ligand & Atom, p. X & Atom, p. Y & Basic Unit & Extra Unit & Ref. \\
\hline 0 & Parvalbumin & 2PVB_A, 0.91 & Ca110_A & $\mathrm{O} / \mathrm{F} 57$ & OG/S55 & $\mathrm{ORI}_{1}$ & N/A & [5] \\
\hline 1 & $\begin{array}{c}\text { BCKD } \\
\text { (branched-chain } \\
\alpha \text {-ketoacid DH) } \\
\end{array}$ & 2BFD_A, 1.39 & K501_A & O/P163 & OG/S161 & $\mathrm{ORI}_{1}$ & $\mathrm{~S} 161, \mathrm{TRI}_{1}$ & [15] \\
\hline 2 & $\begin{array}{c}\text { BCKD } \\
\text { (branched-chain } \\
\alpha \text {-ketoacid DH) }\end{array}$ & 2BFD_A, 1.39 & Mn503_A & $\mathrm{O} / \mathrm{Y} 224$ & OD1/N222 & $\mathrm{ORI}_{1}$ & N/A & [15] \\
\hline 3 & Factor $\mathrm{Xa}$ & 2Y5F_A, 1.29 & Na1245_A & $\mathrm{O} / \mathrm{N} 72$ & OD1/D70 & $\mathrm{ORI}_{1}$ & N/A & [17] \\
\hline 4 & $\begin{array}{c}\text { Pyruvate } \\
\text { dehydrogenase }\end{array}$ & 2OZL_A, 1.90 & Mg2331_A & O/Y198 & OD1/N196 & $\mathrm{ORI}_{1}$ & N/A & [18] \\
\hline 5 & Ribokinase & 1GQT_A, 2.34 & Cs1309_A & $\mathrm{O} / \mathrm{I} 251$ & OD1/D249 & $\mathrm{ORI}_{1}$ & $\begin{array}{l}\text { D249, } \text { TRI }_{1}, \\
\text { R288, TRII } \\
\text { G290, ORII } \\
\text { G2 }\end{array}$ & [16] \\
\hline 6 & Serralysin & 5D7W_A, 1.10 & Ca502_A & $\mathrm{O} / \mathrm{G} 287$ & OD1/D285 & $\mathrm{ORI}_{1}$ & N/A & [19] \\
\hline 7 & Sphericase & 2IXT_A, 0.80 & Ca1311_A & O/V219 & OD2/D217 & $\mathrm{ORI}_{1}$ & N/A & [20] \\
\hline 8 & Stromelysin & 1HY7_A, 1.50 & Ca304_A & O/E184 & OD1/D182 & $\mathrm{ORII}_{1}$ & D182, $\mathrm{TRII}_{1}$ & [14] \\
\hline 9 & Subtilisin Carlsberg & 1R0R_E, 1.10 & Ca302_E & O/T79 & OD1/N77 & $\mathrm{ORI}_{1}$ & N/A & [21] \\
\hline 10 & Subtilisin Nat & 3VYV_A, 1.36 & Ca303_A & $\mathrm{O} / \mathrm{I79}$ & OD1/N77 & $\mathrm{ORI}_{1}$ & N/A & [22] \\
\hline 11 & Thermitase & 1THM_A, 1.37 & Ca301_A & $\mathrm{O} / \mathrm{T} 87$ & OD1/N85 & $\mathrm{ORI}_{1}$ & N/A & [23] \\
\hline 12 & Thermitase & 1THM_A, 1.37 & Ca302_A & $\mathrm{O} / \mathrm{T} 64$ & OD1/D62 & $\mathrm{ORI}_{1}$ & N/A & [23] \\
\hline
\end{tabular}

We found 12 metal cation $(\mathrm{Ca}, \mathrm{Na}, \mathrm{K}, \mathrm{Cs}, \mathrm{Mg}$ and $\mathrm{Mn}$ ) binding sites that use the Clamp,$(\mathrm{n}-2)$ unit (Table 1, Columns 5 and 6). Eleven of them, as, for example, the sites in pike parvalbumin pI 4.10, simultaneously form the $\mathrm{ORI}_{1}$ unit. Only the calcium-binding site of stromelysin [14] possesses 
the $\mathrm{ORII}_{1}$ unit (Figure 1B). A structural description of the $\mathrm{ORII}_{1}$ unit was given in the work of Denesyuk et al. [4]. In stromelysin, in addition to participation in the formation of the $\mathrm{ORII}_{1}$ basic unit, the OD1/D182 atom is used also as a component of the TRII 1 extra unit, in which Asp182 donates main-chain oxygen for direct binding of calcium (Figure 1B). The same structural pattern was found also in branched-chain $\alpha$-ketoacid dehydrogenase, ligand K501 [15]. In ribokinase [16], the OD1/D249 atom participates in three extra units.

\subsection{Metal Cation-Binding Clamp ${ }_{n,(n+2)}$ Unit}

As we have noted above, pike parvalbumin pI 4.10 also has the Clamp $\mathrm{n}_{(\mathrm{n}+2)}$ structural unit, that is in this protein the backbone oxygen atom of Phe57 $\mathrm{n}$ (Position X) and side-chain oxygen atom of Glu59 $_{\mathrm{n}+2}$ (Position Y) directly interact with calcium (Figure 2B and Table 2). However, the OE1/E59 atom does not participate in the formation of the TRI/II basic unit (Figure 1, Table 2, N/A in Column 7). Instead of the OE1/E59 atom, the OE1/E62 atom takes part in the formation of the TRI/II basic unit. Besides, the OE1/E59 atom does not participate in the formation of any other extra ORI/II or TRI/II units (Table 2, N/A in Column 8). Therefore, in this case (lack of the basic/extra ORI/II or TRI/II units:

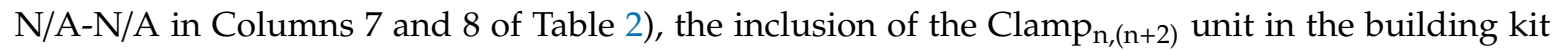
increases the number of modeled atoms that coordinate the bound metal cation. In order to mark the Clamp units possessing such property, we marked the atom in Position Y in bold (Table 2, Column 6).

Table 2. Existence of the Clamp $n,(n+2)$ unit in the metal cation-binding sites of proteins with "niche" motifs in these sites.

\begin{tabular}{|c|c|c|c|c|c|c|c|c|}
\hline $\mathbf{N}$ & Protein & PDB ID, R (Å) & Ligand & Atom, p. X & Atom, p. Y & Basic Unit & Extra Unit & Ref. \\
\hline 0 & Parvalbumin & 2PVB_A, 0.91 & Ca110_A & $\mathrm{O} / \mathrm{F} 57$ & OE1/E59 & N/A & N/A & [5] \\
\hline 1 & Annexin III & 1AXN_A, 1.78 & Ca355_A & O/T193 & OE1/E195 & TRI $_{1}$ & N/A & [24] \\
\hline 2 & Annexin V & 2IE7_A, 1.75 & Ca407_A & O/T31 & OE1/E33 & $\mathrm{TRI}_{1}$ & N/A & [25] \\
\hline 3 & Calcium pump & 1SU4_A, 2.40 & Ca995_A & $\mathrm{O} / \mathrm{I} 307$ & OE1/E309 & $\mathrm{TRI}_{1}$ & N/A & [26] \\
\hline 4 & $\begin{array}{l}\text { Dialkylglycine } \\
\text { decarboxylase }\end{array}$ & 1M0Q_A, 2.00 & K434_A & $\mathrm{O} / \mathrm{L} 78$ & OG/S80 & N/A & N/A & [27] \\
\hline 5 & $\begin{array}{l}\text { Dialkylglycine } \\
\text { decarboxylase }\end{array}$ & 1M0Q_A, 2.00 & K434_A & O/V305 & OD1/D307 & N/A & $\mathrm{L} 78, \mathrm{ORI}_{1}$ & [27] \\
\hline 6 & Peroxidase & 1GWU_A, 1.31 & Ca1307_A & $\mathrm{O} / \mathrm{G} 48$ & OD1/D50 & N/A & N/A & [28] \\
\hline 7 & Peroxidase & 1GWU_A, 1.31 & Ca1308_A & $\mathrm{O} / \mathrm{I} 228$ & OD2/D230 & N/A & N/A & [28] \\
\hline 8 & Serralysin & 5D7W_A, 1.10 & Ca502_A & $\mathrm{O} / \mathrm{G} 255$ & OG1/T257 & N/A & G287, $\mathrm{TRII}_{4}$ & [19] \\
\hline 9 & Serralysin & 5D7W_A, 1.10 & Ca503_A & $\mathrm{O} / \mathrm{G} 288$ & OD2/D290 & N/A & T327, TRII $_{9}$ & [19] \\
\hline 10 & Serralysin & 5D7W_A, 1.10 & Ca503_A & $\mathrm{O} / \mathrm{T} 327$ & OE2/E329 & N/A & $\mathrm{G}_{228}, \mathrm{TRI}_{1}$ & [19] \\
\hline 11 & Serralysin & 5D7W_A, 1.10 & Ca504_A & O/G336 & OD2/D338 & N/A & $\mathrm{A} 353, \mathrm{TRII}_{4}$ & [19] \\
\hline 12 & Serralysin & 5D7W_A, 1.10 & Ca505_A & O/A345 & OD1/N347 & N/A & $\mathrm{G} 62, \mathrm{TRII}_{4}$ & [19] \\
\hline 13 & Serralysin & 5D7W_A, 1.10 & Ca506_A & O/G354 & OD2/D356 & N/A & $\mathrm{A} 371, \mathrm{TRII}_{4}$ & [19] \\
\hline 14 & Serralysin & 5D7W_A, 1.10 & Ca507_A & $\mathrm{O} / \mathrm{G} 372$ & OD2/D374 & N/A & N/A & [19] \\
\hline 15 & Serralysin & 5D7W_A, 1.10 & Ca508_A & O/G363 & OD2/D365 & N/A & N/A & [19] \\
\hline 16 & Sphericase & 2IXT_A, 0.80 & Ca1310_A & O/G297 & OD1/D299 & N/A & $\mathrm{A} 295, \mathrm{ORI}_{1}$ & [20] \\
\hline 17 & Sphericase & 2IXT_A, 0.80 & Ca1311_A & O/V219 & OE1/Q221 & N/A & N/A & [20] \\
\hline 18 & Stromelysin & 1HY7_A, 1.50 & Ca305_A & O/N175 & OD1/D177 & N/A & D141, TRI 1 & [14] \\
\hline 19 & Subtilisin Carlsberg & 1R0R_E, 1.10 & Ca302_E & $\mathrm{O} / \mathrm{L} 75$ & OD1/N77 & N/A & $\mathrm{T} 79, \mathrm{ORI}_{1}$ & [21] \\
\hline 20 & Subtilisin Nat & 3VYV_A, 1.36 & Ca303_A & $\mathrm{O} / \mathrm{L} 75$ & OD1/N77 & N/A & $\mathrm{I} 79, \mathrm{ORI}_{1}$ & [22] \\
\hline 21 & Subtilisin Nat & 3VYV_A, 1.36 & Ca304_A & O/E195 & OD2/D197 & N/A & $\mathrm{T} 174, \mathrm{TRI}_{1}$ & [22] \\
\hline 22 & Thermitase & 1THM_A, 1.37 & Ca302_A & $\mathrm{O} / \mathrm{T} 64$ & OE1/Q66 & $\mathrm{TRI}_{1}$ & N/A & [23] \\
\hline
\end{tabular}

Those atoms that do not participate in the formation of basic and extra ORI/II or TRI/II units are marked in bold.

There are four possible variants of the participation of an atom in the Position $Y$ of the Clamp $n,(n+2)$ unit in the formation of basic and extra units: (1) N/A - N/A, (2) N/A - OR/TR, (3) OR/TR - N/A and (4) OR/TR - OR/TR. Variants 1 and 2 are the most common variants. In serralysin, Variant 2 repeats six 
times. Variant 4 is totally absent in the analyzed structures. For the Clamp $p_{n,(n-2)}$ unit, Variant 3 is the most characteristic (Table 1).

In our systematic analysis of the calcium-binding sites containing the niche motif, we also observed Variant 1 of the Clamp ${ }_{n,(n-2)}$ unit for trypsin: PDB ID 4I8H_A, Ca301_A; Position X, O/N72; Position Y, OE1/E70 [29]. Potentially, this is explained by the presence of a long amino acid Glu in position $(n-2)$ instead of a short one (Asp, Asn, Ser and Thr).

\subsection{Metal Cation-Binding Clamp $p_{n,(n-1)}$ and Clamp $p_{n,(n+1)}$ Units}

We found only four examples of the Clamp $p_{n,(n-1)}$ unit (Figure 2C, Table 3). In all four proteins, the atom in Position $Y$ does not participate in the formation of the basic unit. Three proteins demonstrate a structurally homologous Variant 2 in the formation of the basic and extra units: (N/A - OR/TR). Sodium-binding site of dialkylglycine decarboxylase shows that Clamp $\mathrm{n}_{\mathrm{n},(\mathrm{n}-1)}$, as $\mathrm{Clamp}_{\mathrm{n},(\mathrm{n}-2)}$ and Clamp $\mathrm{n}_{\mathrm{n}, \mathrm{n}+2)}$ units, must be included in the building kit for cation-binding sites.

Clamp $_{n,(n+1)}$ unit is the rarest Clamp unit in comparison with other Clamp units involved in the formation of cation-binding sites (Figure 2D, Table 3). Both Clamp $p_{n,(n-1)}$ and Clamp $p_{n,(n+1)}$ units are equally significant for the formation of the basic and extra units.

Table 3. Existence of the Clamp $p_{n,(n-1)}$ and Clamp $p_{n,(n+1)}$ units in the metal cation-binding sites of proteins with "niche" motifs in these sites.

\begin{tabular}{|c|c|c|c|c|c|c|c|c|}
\hline $\mathbf{N}$ & Protein & PDB ID, R (Å) & Ligand & Atom, p. X & Atom, p. Y & Basic Unit & Extra Unit & Ref. \\
\hline \multicolumn{9}{|c|}{ Clamp $_{n,(n-1)}$ unit } \\
\hline 1 & $\begin{array}{l}\text { Dialkylglycine } \\
\text { decarboxylase }\end{array}$ & 1M0Q_A, 2.00 & Na436_A & O/P99 & OG1/T98 & N/A & N/A & [27] \\
\hline 2 & $\begin{array}{c}\text { Fibroblast } \\
\text { collagenase }\end{array}$ & 1HFC_A, 1.50 & Ca277_A & O/G176 & OD1/D175 & N/A & $\begin{array}{l}\text { G178, } \text { TRII }_{11} \\
\text { N180, }^{\text {ORII }}{ }_{11}\end{array}$ & [30] \\
\hline 3 & Sphericase & 2IXT_A, 0.80 & Ca1310_A & $\mathrm{O} / \mathrm{I} 288$ & OD1/D287 & N/A & $\begin{array}{l}\text { A295, } \text { TRII }_{11}, \\
{\text { G297, } \text { ORII }_{11}}\end{array}$ & [20] \\
\hline 4 & Stromelysin & 1HY7_A, 1.50 & Ca303_A & O/G159 & OD1/D158 & N/A & $\begin{array}{l}\text { G161, TRII } \\
\text { V163, }, \\
\text { ORII } \\
11\end{array}$ & [14] \\
\hline \multicolumn{9}{|c|}{ Clamp $_{n,(n+1)}$ unit } \\
\hline 1 & Annexin III & $1 \mathrm{AXN} \_\mathrm{A}, 1.78$ & Ca352_A & O/G108 & OG1/T109 & N/A & N/A & [24] \\
\hline 2 & $\begin{array}{c}\text { BCKD } \\
\text { (branched-chain } \\
\alpha \text {-ketoacid DH) }\end{array}$ & 2BFD_B, 1.39 & K502_B & O/L130 & OG1/T131 & N/A & N183, TRII 1 & [15] \\
\hline
\end{tabular}

Those atoms that do not participate in the formation of basic and extra ORI/II or TRI/II units are marked in bold.

\subsection{Metal Cation-Binding Clamp ${ }_{n, n}$ Unit}

Table 4 shows 11 examples of the use of the Clamp $p_{n, n}$ unit (Figure 2E) in the calcium-binding sites of proteins. Unlike the four previous types of Clamp units, we found all possible variants of the Clamp $_{n, n}$ unit participation in the formation of the basic and extra units. 
Table 4. Existence of the Clamp $n$,n unit in the metal cation-binding sites of proteins with "niche" motifs in these sites.

\begin{tabular}{|c|c|c|c|c|c|c|c|c|}
\hline $\mathbf{N}$ & Protein & PDB ID, R (Å) & Ligand & Atom, p. X & Atom, p. Y & Basic Unit & Extra Unit & Ref. \\
\hline 1 & Annexin V & 2IE7_A, 1.75 & Ca403_A & $\mathrm{O} / \mathrm{D} 224$ & OD1/D224 & N/A & T227, ORII $_{1}$ & [25] \\
\hline 2 & $\begin{array}{c}\text { BCKD } \\
\text { (branched-chain } \\
\alpha \text {-ketoacid DH) }\end{array}$ & 2BFD_A, 1.39 & K501_A & $\mathrm{O} / \mathrm{S} 161$ & OG/S161 & $\mathrm{TRI}_{1}$ & $\mathrm{P} 163, \mathrm{ORI}_{1}$ & [15] \\
\hline 3 & $\begin{array}{l}\text { Dialkylglycine } \\
\text { decarboxylase }\end{array}$ & 1M0Q_A, 2.00 & Na436_A & O/T98 & OG1/T98 & N/A & N/A & [27] \\
\hline 4 & $\begin{array}{c}\text { Homoserine } \\
\text { dehydrogenase }\end{array}$ & 1EBF_A, 2.30 & Na2104_A & O/E143 & OE2/E143 & TRII $_{1}$ & L150, TRI 1 & [31] \\
\hline 5 & $\begin{array}{l}\text { NaCl-dependent } \\
\text { neurotransmitter } \\
\text { transporter }\end{array}$ & 2A65_A, 1.65 & Na752_A & $\mathrm{O} / \mathrm{T} 254$ & OG1/T254 & TRII $_{1}$ & N/A & [32] \\
\hline 6 & Peroxidase & 1GWU_A, 1.31 & Ca1307_A & $\mathrm{O} / \mathrm{D} 43$ & OD1/D43 & N/A & $\mathrm{G}_{4}, \mathrm{TRI}_{1}$ & [28] \\
\hline 7 & Peroxidase & 1GWU_A, 1.31 & Ca1308_A & O/T171 & OG1/T171 & N/A & $\mathrm{I} 228, \mathrm{TRI}_{1}$ & [28] \\
\hline 8 & Peroxidase & 1GWU_A, 1.31 & Ca1308_A & $\mathrm{O} / \mathrm{T} 225$ & OG1/T225 & N/A & N/A & [28] \\
\hline 9 & Ribokinase & 1GQT_A, 2.34 & Cs1309_A & O/D249 & OD1/D249 & $\mathrm{TRI}_{1}$ & $\begin{array}{l}\text { I251, } \text { ORI }_{1} \\
\text { R288, TRII } \\
\text { G290, } \text { ORII }_{11}\end{array}$ & [16] \\
\hline 10 & Stromelysin & 1HY7_A, 1.50 & Ca304_A & $\mathrm{O} / \mathrm{D} 182$ & OD1/D182 & TRII $_{1}$ & E184, ORII 1 & [14] \\
\hline 11 & Subtilisin Nat & 3VYV_A, 1.36 & Ca304_A & $\mathrm{O} / \mathrm{T} 174$ & OG1/T174 & N/A & N/A & [22] \\
\hline
\end{tabular}

\subsection{System Approach in a Joint Use of OR/TR and Clamp Units}

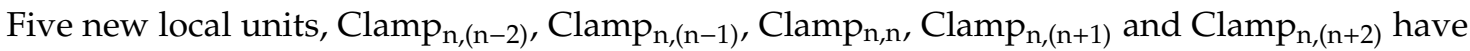
been revealed in spatial structures of the metal cation-binding sites of proteins. Side-chain oxygens of these Clamp units are involved in the formation of both basic and extra OR/TR units. The combination of OR/TR and Clamp units in the same building kit makes it possible to increase the number of modeled atoms that coordinate bound metal cation.

Let us show how the OR/TR and Clamp units are used by Nature to design the complete structure of a calcium (Ca1308_A)-binding site using a three-dimensional structure of peroxidase (PDB ID 1GWU_A) as an example. The mutual spatial arrangement of the OR/TR and Clamp units in this metal cation-binding site is shown in Figure 3. It has three OR/TR units: O/Thr225 $\left(\mathrm{ORI}_{1}\right)$ and $\mathrm{O} / \mathrm{Ile} 228\left(\mathrm{ORI}_{2}\right.$ and $\left.\mathrm{TRI}_{1}\right)$. Their structures include four metal cation-binding atoms: OD1/Asp222, O/Thr225, O/Ile228 and OG1/Thr171. ORI 2 plus TRI 1 units form ADA-DAD (Acceptor/Donor/ Acceptor-Donor/Acceptor/Donor) structural motif, which we described in detail earlier $[5,33]$. There are also three types of the Clamp units in this metal cation-binding site: $\mathrm{O} / \mathrm{Thr} 171\left(\mathrm{Clamp}_{\mathrm{n}, \mathrm{n}}\right), \mathrm{O} / \mathrm{Thr} 225$ $\left(\mathrm{Clamp}_{\mathrm{n}, \mathrm{n}}\right)$ and $\mathrm{O} / \mathrm{Ile228}\left(\mathrm{Clamp}_{\mathrm{n},(\mathrm{n}+2)}\right)$. Their structures include six cation-binding atoms: $\mathrm{O} / \mathrm{Thr} 171$, OG1/Thr171, O/Thr225, OG1/Thr225, O/Ile228 and OD2/D230. A combination of these two sets of atoms provides all seven cation-binding atoms: O/Thr171, OG1/Thr171, OD1/Asp222, O/Thr225, OG1/Thr225, $\mathrm{O} / \mathrm{Ile} 228$ and OD2/D230. The use of seven instead of four atoms in the modeling of the cation-binding site clearly shows the benefits of using the Clamp units. Three atoms OG1/Thr171, O/Thr225 and O/Ile228 are parts of both the OR/TR and Clamp units. The atom OG1/Thr171 and atom O/Thr225 are structural "twins" with respect to the calcium and the O/Ile228 atom. Undoubtedly, the simultaneous use of the nitrogen and oxygen of the main-chain atoms, as well as the oxygen of the side-chain groups of small fragments of the amino acid sequence of the protein to form a cation-binding site is an evolutionarily selected result.

\subsection{Hierarchy of OR/TR and Clamp units}

Water molecules and some other ligands in the $\mathrm{Ca}^{2+}$-binding site do not participate directly in the formation of the Clamp units. At the same time, they can participate in the formation of the ORI/II and 
TRI/II units [4]. The pentapeptide that has metal-binding oxygen in its middle and forms ORI/II and TRI/II units, in some cases, may contain T/S/D/N/E/Q amino acids. It can be assumed that the presence of such ligands in the $\mathrm{Ca}^{2+}$-binding site prevents the formation of some Clamp units. Potentially, these $\mathrm{T} / \mathrm{S} / \mathrm{D} / \mathrm{N} / \mathrm{E} / \mathrm{Q}$ amino acids fulfill some other more important roles and not just participation in the formation of the $\mathrm{Ca}^{2+}$-binding site. In this case, the appearance of water molecules and some other ligands in the $\mathrm{Ca}^{2+}$-binding site helps to compensate for the absence of the Clamp units. This implies the hierarchy in the use of the structural units in constructing of the $\mathrm{Ca}^{2+}$-binding sites: OR/TR units are used first and then Clamp. One of the possible structural explanations for this hierarchy is that only main-chain atoms of the tripeptide participate in ORI/II and TRI/II units, and some atoms of pentapeptide in Clamp units are side-chain atoms.

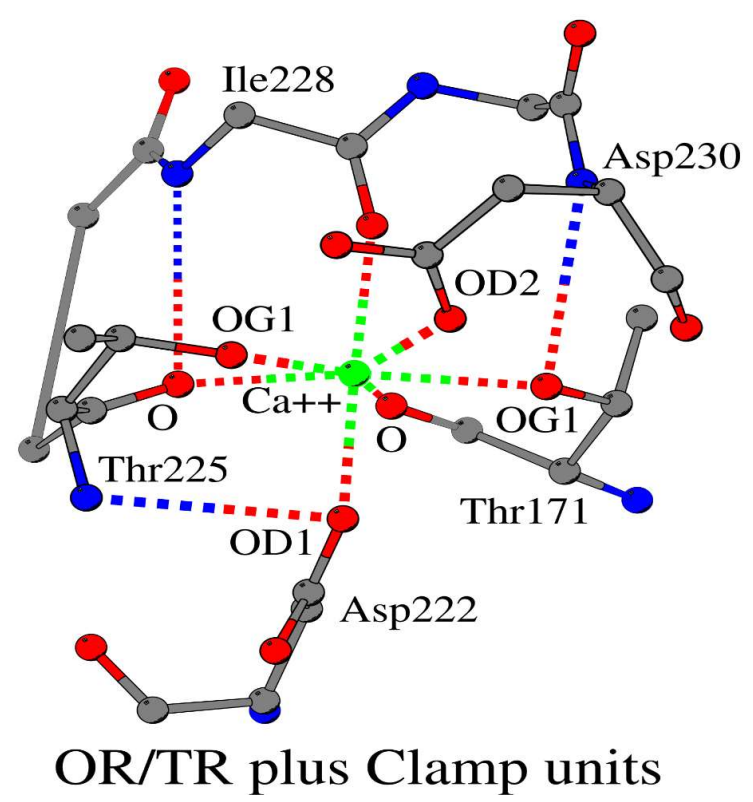

Figure 3. Atomic cation-binding network in peroxidase. Three OR/TR and three Clamp units are shown.

\section{Conclusions}

In the present study, we determined five new local metal cation recognition units in proteins: Clamp $_{n,(n-2)}$, Clamp $_{n,(n-1)}$, Clamp $_{n, n}$, Clamp $_{n,(n+1)}$ and Clamp $n,(n+2)$. Since the interactions of the cations of non-transition elements with their ligands are purely electrostatic without any selected directions, one could suggest that their binding sites in proteins should have a simple design. The results of our work show that this is not the case: these binding sites and their surroundings have a rather complex structure. Nevertheless, they can be presented as a sum of evolutionary selected simple elements, metal cations recognition elements, revealed in our studies. The elements of this "building kit" can be used in protein engineering for the design of metal-binding sites in proteins.

It should be noted that the use of the OR/TR and Clamp structural units cannot explain the construction of absolutely all $\mathrm{Ca}^{2+}$-binding sites. The units found in the present work are based on the binding sites, which contain the main-chain carbonyl oxygen taking part in the coordination of metal ions. There are $\mathrm{Ca}^{2+}$-binding sites, which do not contain main-chain carbonyl oxygens. Moreover, the total structure of some metal-binding sites containing the main-chain carbonyl oxygen cannot be explained using only the OR/TR and Clamp units. Our experience shows that quite often one can explain the tertiary arrangement of three or four out of six possible chelators of a metal atom. The goal of our two publications, the present one and the previous one [4], is to lay the foundation for the creation of a complete "full-fledged building kit". 
Author Contributions: Conceived, designed the study and wrote the manuscript, A.I.D. and K.D.; analyzed the data, S.E.P., M.S.J. and E.A.P.; critically reviewed the manuscript, M.S.J. and E.A.P. All authors have read and agreed to the published version of the manuscript.

Funding: The analysis of calcium-binding protein structures was funded by the Russian Foundation of Basic Research (S.E.P. project \# 19-54-18014). The rest of the project was supported by the Sigrid Juselius Foundation, Joe, Pentti and Tor Borg Memorial Fund (A.I.D. and M.S.J).

Acknowledgments: We thank the Biocenter Finland Bioinformatics Network (Jukka Lehtonen) and CSC IT Center for Science for computational support for the project. The Structural Bioinformatics Laboratory is part of the Drug Development and Diagnostics Platform of Åbo Akademi University.

Conflicts of Interest: We declare that there are no conflict of interest.

\section{References}

1. Permyakov, E.A. Metalloproteomics; A John Wiley \& Sons, Inc.: Hoboken, NJ, USA, 2009.

2. Permyakov, E.A.; Kretsinger, R.H. Calcium Binding Proteins; A John Wiley \& Sons, Inc.: Hoboken, NJ, USA, 2011.

3. Dudev, T.; Lim, C. Principles governing Mg, Ca, and Zn binding and selectivity in proteins. Chem. Rev. 2003, 103, 773-787. [CrossRef] [PubMed]

4. Denesyuk, A.I.; Permyakov, S.E.; Johnson, M.S.; Permyakov, E.A.; Denessiouk, K. Building kit for metal cation binding sites in proteins. Biochem. Biophys. Res. Commun. 2017, 494, 311-317. [CrossRef] [PubMed]

5. Declercq, J.P.; Evrard, C.; Lamzin, V.; Parello, J. Crystal structure of the EF-hand parvalbumin at atomic resolution $(0.91 \AA)$ and at low temperature $(100 \mathrm{~K})$. Evidence for conformational multistates within the hydrophobic core. Protein Sci. 1999, 8, 2194-2204. [CrossRef] [PubMed]

6. Wan, W.Y.; Milner-White, E.J. A natural grouping of motifs with an aspartate or asparagine residue forming two hydrogen bonds to residues ahead in sequence: Their occurrence at alpha-helical $\mathrm{N}$ termini and in other situations. J. Mol. Biol. 1999, 286, 1633-1649. [CrossRef] [PubMed]

7. Wan, W.Y.; Milner-White, E.J. A recurring two-hydrogen-bond motif incorporating a serine or threonine residue is found both at alpha-helical $\mathrm{N}$ termini and in other situations. J. Mol. Biol. 1999, 286, 1651-1662. [CrossRef]

8. Duddy, W.J.; Nissink, J.W.; Allen, F.H.; Milner-White, E.J. Mimicry by asx- and ST-turns of the four main types of beta-turn in proteins. Protein Sci. 2004, 13, 3051-3055. [CrossRef]

9. Torrance, G.M.; Leader, D.P.; Gilbert, D.R.; Milner-White, E.J. A novel main-chain motif in proteins bridged by cationic groups: The niche. J. Mol. Biol. 2009, 385, 1076-1086. [CrossRef] [PubMed]

10. Berman, H.M.; Westbrook, J.; Feng, Z.; Gilliland, G.; Bhat, T.N.; Weissig, H.; Shindyalov, I.N.; Bourne, P.E. The Protein Data Bank. Nucleic Acids Res. 2000, 28, 235-242. [CrossRef]

11. Berman, H.; Henrick, K.; Nakamura, H. Announcing the worldwide Protein Data Bank. Nat. Struct. Biol. 2003, 10, 980. [CrossRef]

12. Sobolev, V.; Sorokine, A.; Prilusky, J.; Abola, E.E.; Edelman, M. Automated analysis of interatomic contacts in proteins. Bioinformatics 1999, 15, 327-332. [CrossRef] [PubMed]

13. Kraulis, P.J. MOLSCRIPT: A program to produce both detailed and schematic plots of protein structures. J. Appl. Cryst. 1991, 24, 946-950. [CrossRef]

14. Natchus, M.G.; Bookland, R.G.; Laufersweiler, M.J.; Pikul, S.; Almstead, N.G.; De, B.; Janusz, M.J.; Hsieh, L.C.; Gu, F.; Pokross, M.E.; et al. Development of new carboxylic acid-based MMP inhibitors derived from functionalized propargylglycines. J. Med. Chem. 2001, 44, 1060-1071. [CrossRef] [PubMed]

15. Machius, M.; Wynn, R.M.; Chuang, J.L.; Li, J.; Kluger, R.; Yu, D.; Tomchick, D.R.; Brautigam, C.A.; Chuang, D.T. A versatile conformational switch regulates reactivity in human branched-chain $\alpha$-ketoacid dehydrogenase. Structure 2006, 14, 287-298. [CrossRef] [PubMed]

16. Andersson, C.E.; Mowbray, S.L. Activation of ribokinase by monovalent cations. J. Mol. Biol. 2002, 315, 409-419. [CrossRef] [PubMed]

17. Salonen, L.M.; Holland, M.C.; Kaib, P.S.; Haap, W.; Benz, J.; Mary, J.L.; Kuster, O.; Schweizer, W.B.; Banner, D.W.; Diederich, F. Molecular recognition at the active site of factor Xa: Cation- $\pi$ interactions, stacking on planar peptide surfaces, and replacement of structural water. Chemistry 2012, 18, $213-222$. [CrossRef] [PubMed] 
18. Seifert, F.; Ciszak, E.; Korotchkina, L.; Golbik, R.; Spinka, M.; Dominiak, P.; Sidhu, S.; Brauer, J.; Patel, M.S.; Tittmann, K. Phosphorylation of serine 264 impedes active site accessibility in the E1 component of the human pyruvate dehydrogenase multienzyme complex. Biochemistry 2007, 46, 6277-6287. [CrossRef]

19. Wu, D.; Ran, T.; Wang, W.; Xu, D. Structure of a thermostable serralysin from Serratia sp. FS14 at $1.1 \AA$ resolution. Acta Crystallogr. F Struct. Biol. Commun. 2016, 72, 10-15. [CrossRef]

20. Almog, O.; González, A.; Godin, N.; de Leeuw, M.; Mekel, M.J.; Klein, D.; Braun, S.; Shoham, G.; Walter, R.L. The crystal structures of the psychrophilic subtilisin S41 and the mesophilic subtilisin Sph reveal the same calcium-loaded state. Proteins 2009, 74, 489-496. [CrossRef]

21. Horn, J.R.; Ramaswamy, S.; Murphy, K.P. Structure and energetics of protein-protein interactions: The role of conformational heterogeneity in OMTKY3 binding to serine proteases. J. Mol. Biol. 2003, 331, 497-508. [CrossRef]

22. Ushijima, H.; Fuchita, N.; Kajiwara, T.; Motoshima, H.; Ueno, G.; Watanabe, K. Crystal structure of subtilisin NAT at $1.36 \AA .2013$; in press.

23. Teplyakov, A.V.; Kuranova, I.P.; Harutyunyan, E.H.; Vainshtein, B.K.; Frommel, C.; Hohne, W.E.; Wilson, K.S. Crystal structure of thermitase at $1.4 \AA$ resolution. J. Mol. Biol. 1990, 214, 261-279. [CrossRef]

24. Favier-Perron, B.; Lewit-Bentley, A.; Russo-Marie, F. The high-resolution crystal structure of human annexin III shows subtle differences with annexin V. Biochemistry 1996, 35, 1740-1744. [CrossRef] [PubMed]

25. Colloc'h, N.; Sopkova-de Oliveira Santos, J.; Retailleau, P.; Vivarès, D.; Bonneté, F.; Langlois d'Estainto, B.; Gallois, B.; Brisson, A.; Risso, J.J.; Lemaire, M.; et al. Protein crystallography under xenon and nitrous oxide pressure: Comparison with in vivo pharmacology studies and implications for the mechanism of inhaled anesthetic action. Biophys. J. 2007, 92, 217-224. [CrossRef] [PubMed]

26. Toyoshima, C.; Nakasako, M.; Nomura, H.; Ogawa, H. Crystal structure of the calcium pump of sarcoplasmic reticulum at $2.6 \AA$ resolution. Nature 2000, 405, 647-655. [CrossRef] [PubMed]

27. Liu, W.; Rogers, C.J.; Fisher, A.J.; Toney, M.D. Aminophosphonate inhibitors of dialkylglycine decarboxylase: Structural basis for slow binding inhibition. Biochemistry 2002, 41, 12320-12328. [CrossRef] [PubMed]

28. Henriksen, A.; Brissett, N.; Gajhede, M. Hrpc heme crevice architecture. 2003; in press.

29. Liebschner, D.; Dauter, M.; Brzuszkiewicz, A.; Dauter, Z. On the reproducibility of protein crystal structures: Five atomic resolution structures of trypsin. Acta Crystallogr. D Biol. Crystallogr. 2013, 69, 1447-1462. [CrossRef] [PubMed]

30. Spurlino, J.C.; Smallwood, A.M.; Carlton, D.D.; Banks, T.M.; Vavra, K.J.; Johnson, J.S.; Cook, E.R.; Falvo, J.; Wahl, R.C.; Pulvino, T.A.; et al. $1.56 \AA$ structure of mature truncated human fibroblast collagenase. Proteins 1994, 19, 98-109. [CrossRef] [PubMed]

31. DeLaBarre, B.; Thompson, P.R.; Wright, G.D.; Berghuis, A.M. Crystal structures of homoserine dehydrogenase suggest a novel catalytic mechanism for oxidoreductases. Nat. Struct. Biol. 2000, 7, 238-244. [PubMed]

32. Yamashita, A.; Singh, S.K.; Kawate, T.; Jin, Y.; Gouaux, E. Crystal structure of a bacterial homologue of $\mathrm{Na}^{+} / \mathrm{Cl}^{-}$-dependent neurotransmitter transporters. Nature 2005, 437, 215-223. [CrossRef]

33. Denessiouk, K.A.; Johnson, M.S. "Acceptor-donor-acceptor" motifs recognize the Watson-Crick, Hoogsteen and Sugar "donor-acceptor-donor" edges of adenine and adenosine-containing ligands. J. Mol. Biol. 2003, 333, 1025-1043. [CrossRef] [PubMed]

(C) 2020 by the authors. Licensee MDPI, Basel, Switzerland. This article is an open access article distributed under the terms and conditions of the Creative Commons Attribution (CC BY) license (http://creativecommons.org/licenses/by/4.0/). 